\title{
Trials of the Islamic Education Learning Model in Indonesian Universities: A Sufistic Approach as An Alternative
}

\author{
Munawar Rahmat ${ }^{1} \&$ M. Wildan Bin Hm Yahya ${ }^{2}$ \\ ${ }^{1}$ Indonesia University of Education, Bandung, Indonesia \\ ${ }^{2}$ Bandung Islamic University, Bandung, Indonesia \\ Correspondence: Munawar Rahmat, Indonesia University of Education, Bandung, Indonesia.
}

Received: November 8, 2020

doi:10.5430/ijhe.v10n2p253
Accepted: December 3, $2020 \quad$ Online Published: December 9, 2020

URL: https://doi.org/10.5430/ijhe.v10n2p253

\begin{abstract}
The students of Indonesia University of Education (UPI) and Bandung Islamic University (UNISBA) typically practice religion as it was received from their parents and socio-religious environment. They Salat, which is the main prayer of Islam, simply abort their obligations, and after praying, immediately leave their prayer mats without making dhikr or remembering God first. Furthermore, they do not understand khushu Salat, which involves remembering God throughout the prayer, along with the meaning of dhikr, and the importance of a Murshid, which is the Grand Shaykh of Sufi Order. They also view Sufism as non-Islamic teaching and are cynical about the practitioners. Therefore, this study aims to examine the effectiveness of the Sufistic learning model in Islamic Religious Education to improve students' understanding of these teachings in a substantive and tolerant manner. This research used an $R \& D$ approach, and the stage that was performed involved the preparation of a draft model and associated trials. Meanwhile, the learning used the madhhab typology approach of the Sufi and Shari a Islamic models. The trial results showed that the Sufistic approach was effective in increasing students' understanding of Islamic teachings in a substantive and tolerant manner. Before learning, students were unaware of Sufi Islam and viewed it as a foreign influence. Also, they did not understand khushu prayers, comprehend the importance of $d h i k r$, nor that of learning from Murshid. After learning, they understood Sufism, accepted the teachings and did not consider them to be foreign influences, and also recognized Islam in a substantive and tolerant manner. Therefore, the Sufism approach is improving the quality of religion and tolerance of students, with the implication that the model is an alternative in learning Islamic education at universities.
\end{abstract}

Objective: This study aims to examine the effectiveness of the Sufistic learning model in Islamic Religious Education to improve students' understanding of Islamic teachings in a substantive and tolerant manner.

Methods: A research and development $(\mathrm{R} \& \mathrm{D})$ approach, which was performed in the preparation of a draft model and associated trials, was used. Meanwhile, the learning employed the madhhab typology approach of the Sufi and Shari a Islamic model.

Results: The trial results showed that the Sufistic approach in Islamic Education was effective in increasing students' understanding of Islamic teachings in a substantive and tolerant manner. Before learning, students unfamiliar with Sufi Islam, saw it as a foreign influence, and did not understand khushu Salat, which involves remembering God throughout the prayer. Also, they considered dhikr, which means to remember God, and learning from Murshid as unimportant. However, they understood Sufism, accepted it as Islamic teachings and not foreign influences, and recognized the religion in a substantive and tolerant manner after the learning process.

Conclusion: The Sufism approach in Islamic Education has succeeded in improving the quality of religion and tolerance of students.

Keywords: religious education at universities, the Madhhab typology approach of the Sufi and Shari a Islamic, Islamic substantive, religious tolerance

\section{Introduction}

Although Sufism is widely known in the Muslim community, only some people understand and practice it, while General Islam is mostly performed by the public. Along with increasing age and religious education, some persons observe Islam and perform their lives in a Sufistic way. 
Islam in Indonesia has unique characteristics that are inseparable from Sufism and the Tariqa or Sufi Order. This practice played a large role in entering and developing Islam in the archipelago (Howell, 2001; Ghaffar, 2015). Furthermore, the XVII-XVIII centuries were the golden era of Sufism in Indonesia (Taufani, 2018), and these teaching have remained alive in the modern age. Although Sufis in the 21 st century can compete globally, and some are materially rich, they are not dazzled by wealth and position (Andarwati, 2016).

Sufism and Tariqa are significant esoteric dimensions in the practice's perfection of Islamic teachings (Siregar, 2012), while Shari' $a$ is exoteric. The practice of these two dimensions can perfect physical birth (Mannan, 2018) thus, the rejection of Sufism has no place in Indonesia. Sufism and Tariqa have four aspects that are very useful for life, namely mystical, ethical, popular, and communal. While the mystical dimension leads a Sufi to "be with God," the ethical equivalent leads people to behave well towards "fellow human beings." The popular dimension guides persons to "be together in the way of Allah," while the communal counterpart guides one to "be with fellow Sufis" (Riyadi, 2018).

However, there was a later rejection of Sufism, as some accused this practice of being influenced by Christianity and Greek philosophy (Hilal, 2002: 19-20), as well as Indian religion (Rahmatul Husni, 2017). Sufism was accused of not having an Islam origin (Ibrahim, 2002: 83-100), an allegation that was rejected by the followers of this practice, as according to Harun Nasution, Sufism and the Tariqa have a firm basis in Islamic teachings (Harun Nasution, 1990: 112). Moreover, Tariqa thrives in Indonesia and the largest Islamic organization in this country (NU), which was created to be autonomous, houses this order (Kholid, 2018). Meanwhile, some persons proposed that Sufism should be entered into the Islamic Education Institute curriculum (Suteja, 2017) as the benefits of Sufism and Tariqa were observed in several research results. Salat and dhikr, which are the major forms of Sufism charity can increase emotional intelligence, self-control, and eliminate stress (Harmathilda H. Soleh, 2017). Furthermore, workers in Pontianak, as well as the observers and congregation of Qadiriyah Naqsyabandiyah Tariqa (TQN), are considered to have noble characters. They particularly exhibit siddiq, which translates to righteousness, and amanah, meaning trust because they believe in being constantly supervised by God (Fatmawati, 2013). Also, they experience significant peace of mind before and after receiving dhikr training for the elderly (Kumala et al., 2017).

\section{How is Islamic Religious Education (PAI) in schools and colleges?}

PAI, like other religious education, is considered to have failed to build a substantive and tolerant religiosity. The results of research in 2006 and 2009 show that the style of religious thinking in West Java tends to be exclusive and intolerant (Rahmat, 2012), and studies in 2019 and 2020 reveal similar results. More than half of UPI students are intolerant of other religions and minority Islamic schools. However, through changes in the learning model, by approaching the study of religions and the typology of schools, increasing their tolerance was successful (Rahmat $e t$ al., 2019; Rahmat et al., 2020). This situation was the same at schools, as approximately half of the high school pupils in big cities, such as Jakarta, Bandung, and Surabaya were intolerant (Firdaus \& Rahmat, 2016). The research results from SMP were interesting, as although the Muslim students in West Java were much more religious concerning theology and rituals than the Christians, they were intolerant. Hence, the Christian students were much more tolerant than Muslims but less religious, and no correlation was found between religiosity and tolerance (Rizal \& Rahmat, 2019). Criticism of Religious Education in the United Kingdom builds exclusive diversity but fails to engender mutual understanding among adherents (Clayton \& Stevens, 2018). Meanwhile, they recommended the Education of Religions. However, their criticism of the failure of education in Great Britain is not quite right, as Dinham \& Shaw, as well as the Commission on RE, report that this teaching fosters mutual understanding and religious tolerance (Barnes, 2020).

Although PAI uses various approaches in higher education, a Sufistic method seems more appropriate to improve the quality of a substantive and tolerant religion.

\section{Methods}

This study aims to examine the effectiveness of the Sufistic learning model in increasing PAI students' understanding of Islamic teachings in a substantive and tolerant manner. An R\&D approach was employed, which comprised three stages, namely preliminary studies, which involve the theoretical study and drafting of models, as well as trials, which are limited and broader, and validation (Sukmadinata, 2009). Hence, the research conducted used only a preliminary study stage and limited model trials. The model was drafted by using the madhhab typology of the Sufi, which combines the inner and outer aspects of worship, as well as Shari a Islamic teachings. Meanwhile, Shari a Islam only emphasizes the outer aspects, e.g. prayer, where the birth aspect is body worship. This worship is in the form of standing, bowing, prostration, and sitting facing the Qibla, accompanied by prayer recitation from takbiratul ihram to greeting. Conversely, the inner aspect involves presenting God in the heart and remembering Him throughout the prayer. 
The madhhab or school typology was adapted from the method of Ali Shari a's religion, which stated that this approach was a special technique and is useful for studying religions. This method has two important characteristics, which are identifying the main religious aspects, such as God, Prophet, and Holy Scriptures, while the second compares them with similar forms in other religions (Dabla, 1992). The main purpose of this method is to improve the understanding of communities for their religion and the tolerance of others. Meanwhile, the main objective of the typology method was to enhance the understanding of Muslims for their madhhabs by comparing them objectively with other schools and increasing their tolerance towards other Islamic groups.

The meaning of madhhab in the typology method is "real schools in society," not classical or theoretical schools. Here, the characteristics of the school are teachings, congregations, scholars, and educational institutions, e.g., Sunni IslamShi'a Islam, NU-Muhammadiyah, also includes Shari`a Sufi-Islam. In Indonesia, Sufi and general Islam have unique teachings, which combine the physical and mental aspects of worship. Also, there are congregations, especially Tariqa followers, as well as scholars, particularly Murshid Teachers, and educational institutions from kindergarten and elementary to university. The madhhab typology method has two important characteristics, which are to identify the main aspects of the school and to compare them with others. This study used the importance of khushu prayer, which involves presenting God in the heart during the prayer, dhikr, which means remembering God, and the Murshid Teacher as the main aspects.

A typology method for the Sufi-Islamic Shari a school of typology was drafted and tested in 6 PAI lectures for six (6) weeks in the odd semester of 2019-2020 at UPI and UNISBA. Two classes were each selected, which include the Accounting study program for both schools, as well as Islamic Religious Education for UPI, and Islamic Communication \& Broadcasting for UNISBA, individually.

Then, a qualitative-evaluative data analysis was performed by recording student responses to the typical teachings of Sufi Islam during the six lectures. Three major questions were asked, which were the importance of the khushu' prayer, the significance of $d h i k r$, especially during prayer and the remembrance afterward, as well as the need for Muslims to have Murshid Teachers or authoritative scholars. The answers expected from students were that prayers must be done with khushu', dhikr was important during and after prayer, and that it was necessary to learn from authoritative scholars, either Murshid Teachers or not, to understand true Islam.

\section{Results}

\subsection{The Existence of Sufism and Tariqa}

Based on the literature review, there have been debates about the pros and cons of Sufism. Anti-Sufism groups, such as Hilal, say that the core of this practice is the Ma 'rifat bi Allāh, which is to recognize God. It is said that this core is achieved through kashaf, meaning God reveals himself, even though this concept is the same as the gnosis process of Greek Philosophy (Hilal, 2002: 19-20). Meanwhile, the book owned by Ibrahim and titled Tasawuf dan Pengaruh Asing, meaning Sufism and Foreign Influence, states that the life of the Sufi is not derived from Islam (Ibrahim, 2002: 83-100). "The teachings of Sufism are 'by-products' originating from the Hindu Upanishads and Vedanta, as well as Hellenism traditions, Christian mysticism, Neo-Platonism, or Stoicism" (Rahmatul Husni, 2017). Anwar also wrote books, which were titled "Kenapa harus tasawuf, bukankah ada akhlak?" meaning "Why should Sufism, aren't there morals?" and three others under the umbrella of "Tasawuf tanpa Tarekat," which translates to "Sufism without Tariqa"). This author further stressed that committing Sufism is moral (Anwar, 2002: 3-8), while Tasawuf challengers further argue that Sufis cannot account for their eschatic remarks (Iu Rusliana, 2016).

Harun Nasution strongly denied that Sufism originated from outside of Islam, and these views can be summarized in a few points. This scholar argues that The Prophet SAW lived as a Sufi, and Khulafa al-Rāshidîn (Abu Bakar, Umar, Uthman, Ali), as well as senior Sahaba, all friends of the Prophet SAW, emulated the Sufi life. Also, when the Caliphate was in the hands of the corrupt nepotists Mu awiyah and Abbasiyah, many scholars lived as Sufis, and finally, the teachings of this practice have strong roots in the Qur'ān and Hadith (Harun Nasution, 1990: 1-12).

In Indonesia, the Sufis are called experts as carriers of Islamic teachings in the Archipelago, and some scholars follow these teachings (Suryanegara, 1998: 160-161). Some Sufi figures in the modern era are KH Muhammad Munawar Affandi, Kiai Muhammad Anwar Muttaqin (Shattariah Tariqa) (Rahmat, 2018a), Abah Anom (TQN), Sheikh Abdul Wahab Rokan, and Sheikh Hasan Maksum (Naqshabandiyah Tariqa) (Ja'far, 2016). From the aspect of mass organizations, NU is known to develop Tariqa, unlike Muhammadiyah, which is Indonesia's second-largest Islamic organization, and does not develop this order but accepts Sufism (Maisyaroh, 2019). This organization, which wants to return Sufism to fit the Qur'ān and Sunnah, does not forbid this practice as the Salafi but wishes to prevent it from deviating from the path (Al-Kumayi, 2013). 


\subsection{PAI Learning Process with a Sufistic Approach}

Before learning, most students were unaware of Sufism, and those that knew were mostly negative, while few were positive. PAI learning aims to make students understand the meaning of Sufism and improve the quality of their religion by teaching three themes. These themes were concerned with if meeting the conditions of harmony was enough or being devoted was the better way to pray. Also, they were regarding the definition of and practice of $d h i k r$ and the need for pupils to study with the Murshid or any cleric. A summary of the meaning of the three themes from the perspectives of Sufi and General Islam are in the following table:

Table 1. The PAI Material in view of Sufi and Shari ${ }^{a}$ Islam

\section{No The PAI \\ Material}

Sufi Islam

1 Khushu Salat
Sufi Islam has a method. Shari' $a$ without essence is fasiq, which means disobeying Allah and His Messenger, while essence without Shari'a is zindik (munafiq). Both are bad.

- Salat must fulfill the conditions of harmony, which are to present Allah and remember Him throughout the prayer. Even outside, Salat also maintains these special conditions (Rahmat, 2010).

- In the perspective of the Tariqa, Salat functions to connect the servant to God. It that presents the heart is the best Salat for Tariqa experts. The Prophet also reminded, "La Salata illâ bi hudhûr al-qalb, meaning there is no Salat without the presence of the heart." Salat for salikin or Tariqa people is both an abortion and an enjoyment. Therefore, their lives seem intended for Salat, and they are serious about establishing the obligatory, circumcision, and evening Salats (tahajud). These people are so addicted to Salat and dhikr (Nasarudin Umar, 2014).

- A hadith mentioned that other deeds will be checked after the Salat is correct. If the Salat is wrong, then other charities will be counted. If it is wrong and does not serve the purpose, which is remembering Allah, then it deletes the other deeds. Salat is like the number one (1) in front while other charities are like zero (0) at the back. Consequently, the zero behind will be valuable if one is in front of it but is worthless if followed by more zeros. The number 100 is valuable but $0,000,000,000,000$, even if the zeros behind are as long as a railroad track, is worthless (Rahmat, 2010).

- The purpose of Salat is li al-dhikrî, meaning "remembering" God (Q.S. Taha [20]: 14). If this is not fulfilled, then it means sâhûn or negligent and is threatened with hell (Q.S. al-Ma`un [107]: 4-5) (Qur’ān, 2013).

\section{Shari a Islam \\ (General Islam)}

General Islam emphasizes the implementation of worship by blending Shari'a. Some emphasize the essence while others do not.

- NU emphasized the worship services by collecting Shari'a and the essence. According to $\mathrm{NU}$, Salat is worship aimed at remembering Allah, as forgetting Him is a big mistake.

According to the Word, "Do not be among those who forget" (Q.S. Al-A'raf [7]: 205). It is also addressed to those that pray only to meet the conditions and abort the obligations. Then, Salat is dry without the presence of the heart, and although the mouth looks busy, not a single raka at is understood. Hence, the heart of such a person is filled with worldly problems.

The Messenger of Allah said: "Allah does not look at the Salat of someone that does not present or concentrating with heart and body." Even more, Allah SWT (Q.S. al-Maun [107]: 4-5) threatens those that pray in a state of neglect or emptiness, as this means that Salat is done without being accompanied by solemnity (NUonline, 2019).

- According to Muhammadiyah, Salat is valid if it fulfills the conditions and harmony. These conditions include facing the Qibla, covering the genitals, and being pure from the hadats or uncleanliness. Several pillars must be fulfilled during Salat, such as intention, takbiratul ihram, and reciting Surah Al-Fatihah on each raka'at. Others are bowing, i'tidal, and prostration with tuma'ninah or calm and peace, as well as sitting in between two prostrations. More pillars are sitting tashahud and reciting the Salats simultaneously, alongside reciting Salat to the Prophet and saying greetings.

Khushu in Salat is only the perfection of Salat, and not conditions or harmony. With the existence of tuma'ninah in performing the Salat, it is implied that these prayers can be done as well as possible, as an effort to achieve solemnity (Suara Muhammadiyah, 2019). 


\section{Dhikr}

Dhikr from the Tariqa perspective is to remember Allah in the heart. Meanwhile, the meaning in Salat is to remember and mention the name of God verbally and mentally.

- In the TQN order, dhikr is an oral and heartfelt activity that involves mentioning and remembering the names of Allah. There are two kinds, namely jahr or loud, by saying Là ilāha illä Allāh, and khafy, meaning noiseless, performed by reciting ism $d z \bar{a} t$ (Allah, Allah, etc.) in the heart. Dhikr is only legitimate if it has been talqin/berkah or blessed by the Murshid teacher (Marwa Salahudin \& Arkuni, 2016).

- The symbolic meaning of dhikr is that the nature of every work is part of remembering Allah, and remembrance is a pleasure because the mortality of life is felt. Other meanings are that the enjoyment gives birth to the tranquility of the soul and that the most important part is feeling ma'rifatullah or recognizing God (Izzah Faizah Siti Khaerania \& Yuyun Nurlaen, 2019).

- The meaning of remembrance in Shattariah Tariqa is the recollection of conscience, spirit, and taste for the Substance of Allah, even though Al-Ghäib, the only thing that is unseen, is His Obligatory Form. "This is Ana (I am), My Name is Allah." Remembrance unites the core of a man, from which the seed of nature comes. The true essence of dhikr is not the jahr or chanting Allah's Name because that is the only known detail. Although the name is the same, it can do nothing. The one that can do anything is His Musamma or owner of the Name or Substance. To understand the Substance of Allah, experts, such as ahl dhikr and the Wasithah teacher must be asked (Rahmat, 2010).

- God should be remembered in the heart at the same time as inhaling. It is also advisable to practice breathing deeply and slowly while remembering God and then exhaling slowly. The commonly read devotions, including the fardhu Salat or obligatory prayers and Tahajud Salat in the Shattariah Tariqa are called muqaddimah dhikr. It also means dhikr after fardhu or tahajud Salat (Rahmat, 2010).

3 Murshid Sufi Islam views the existence of the Shaykh or Murshid Teacher teacher as important.

- According to Imam Ghazāli, the guidance of a teacher is an absolute requirement for the successful development of any religion. Without it, a person will fall into error. The Imam further revealed that "someone without a teacher is the teacher" (Afandi, 2001; (Akmansyah, 2015).

- The existence of the Murshid teacher is to fulfill the commands of Allah, Fas'alu ahl al-dhikr inkuntum la ta lamun. This means, "so ask the Ahl al-dhikr or expert in remembering God if you do not know Him" (Q.S. al-Nahl [16]: 43 \& Q.S. al-Anbiya [21]: 7) (AlQuran).
Dhikr of the general religious community refers to the meaning according to NU and Muhammadiyah.

- According to NU, the dhikr of Allah SWT has three categories. First, the $d h i k r$ of His Names is performed by those that are at the stage of seeking peace with Allah for all events related to themselves. Second, dhikr of His Nature, which is done by those that love Allah, and the third is of His Substance, which ignores all connections of the universe to Him.

- The substance is only remembered with no physical or mental strings attached. Hence, every Muslim that $d h i k r$ will be inseparable from the three categories of remembrance (KH Said Aqil Siraj, 2013).

Salat and dhikr are highly recommended anytime and anywhere, even more so after the five daily prayers. Dhikr after Salat five times brings one closer to ijabah, which is granted by Allah. Salat and $d h i k r$ have their virtues in congregations. Rasulullah SAW mentioned angels, mercy, the emergence of peace, and praise of Allah SWT (NUonline, 2018).

- There are three kinds of dhikr regarding Muhammadiyah, which are of heart, tongues or oral, and limbs. Dhikr with heart concerns arguments about the Substance and attributes of God. It also involves arguments that show the burden or taklif, laws, commands, prohibitions, promises, and threats of Allah, as well as the secrets of His creation. Dhikr with tongues refers to praising Allah, glorifying, and reading the Qur'an, while that with limbs indicates the five daily Salats. The Salat dhikr is performed individually and in a low voice. Recitation in congregations is prohibited, except it has not been memorized, and the priest intends it as guidance (Pimpinan Pusat Muhammadiyah, 2017).

General Islam does not acknowledge the Murshid teacher but encourages people to practice Islam by referring to the Ulama.

- According to NU, the Kiai or Ulama are people that master the Salaf or previous Ulama, AlQur'ān, and hadith books. Also, they serve as examples to the people, are accepted by the community, and have a religious-national commitment that is based on inclusive Islam. However, these people are not "Kiai karbitan" who only follow the tastes of the times and the capital market. This type of people are often found in electronic media, such as TV, radio, or the internet, as well as in print media, which includes newspapers, tabloids, or magazines. It is 
Ahl al-dhikr is the Murshid teacher that became so because of a delegation received from the previous Murshid teacher that has a genealogy that continues to Rasûlullah SAW (Izzah Faizah Siti Khaerania \& Yuyun Nurlaen, 2019).

- From the perspective of Shattariah Tariqa in Nganjuk, East Java), the Murshid or Wasithah teacher was the deputy or successor of Prophet Muhammad in continuing the mission and hard work. Therefore, there is only one Wasithah Teacher in every period. Al-Qur'ān calls it with various titles, among others. These include Al-Wasîlata or intermediary between the servant and God, as well as Ahl al-dhikr. They are also called Waliyan Murshidan or Murshid teacher, and Imâmun Mubîn, which means the Imām that is present amid the Ummah (Rahmat, 2010).

- According to the TQN Tariqa, there can be several Murshid teachers in a period. also not "Kiai Genetika," which is a kiai descendant considered as such because of parentinherited charisma, even without an Ulama qualification (Romzi, 2012).

- According to Muhammadiyah, Ulama must have a science and moral qualification. From the scientific aspect, the Al-Qur`ān, authentic hadith, ulum al-dîn, Islamic, and contemporary thoughts should be properly understood. Also, the strategies and tactics of the struggle encountered should be comprehended and applied with wisdom. Additionally, the moral qualifications the Ulama must possess is fear of Allah, and not hubb al-dunya or love for the world, especially to the point of being insane or disrespectful (Isnanto, 2018).

- NU and Muhammadiyah have the same religious reference, which is the Qur'ān and authentic hadith. NU understands it through the Salaf books, especially from the Shafi i madhhab, while Muhammadiyah directly refers to the two sources of Islam (Sembodo Ardi Widodo, 2011).

Before studying, students did not understand Sufism. Those who understand tend to be negative, seeing Sufism as a foreign influence. After studying the typology approach of the school, they understood that Sufism has strong roots from the main sources of Islam, the Qur`ān and hadith. Regarding khushu` prayer, some Islamic shari`a also requires it. Some others do not oblige, but see it as a good deed. Regarding dhikr, Islamic shari a also obliges it. This means that these two teachings - khushu' prayer and $d h i k r$ - are not unique to Sufism. But the previous students didn't understand. After learning, students feel confident that khushu prayer and dhikr are the main acts of worship in Islam.

Regarding the importance of studying from Murshid, Islamic shari`a does not recognize it at all. But there are basic equations that every Muslim needs to learn from the Ulema heir of the Prophet, do not just learn religion from anyone. Moreover, don't learn religion from social media whose identities are not clear, because these media contain intolerant Islamic teachings. After the lecture, students see the importance of studying from the Murshid Teacher or Ulema who inherits the Prophet.

\section{Discussion}

\subsection{Discussion of the Pros and Cons of Sufism and Tariqa}

The results of the literature study the pros and cons of Sufism and the Tariqa. While counter groups accuse Sufism of not originating from Islam, pro groups emphasize it as Islamic teachings. However, the influence of Sufism in Indonesia is difficult to stem because, first, NU as the largest Islamic mass organization practices it and supports Tariqa. It also has "Jam'iyyah Ahli al-Thariqah al-Mu'tabarah al-Nahdliyyah," which is a Tariqa organization that coordinates the Sufi orders. Meanwhile, 45 Tariqas were declared mu'tabarah or valid (Kholid, 2018).

Second, there are two well-known figures of Sufism among Muslims, namely Sheikh Abdul Qadir Jailani, better known as Sayyidul Auliya or King of the Guardians, and Imam Ghazāli, also called Hujjah al-Islam or King of the Ulamas (Nadzirotul Masruroh, 2018). However, Al-Ghazāli became the Murshid Teacher (Afandi, 2001) and confirmed the guidance of a Shaykh as an absolute condition for the success of spirituality. "Therefore, a person will fall into error without the Shaykh" (Akmansyah, 2015).

Third, the Tariqa has a large following, as Shattariah Tariqa, which began in the XVII century AD had a big role in Indonesia. In 1886 AD Kiai Hasan Ulama established the first modern boarding school, which was followed by many Ulama. During the time of the 47th Wasithah Teacher, Kiai Moh. Kusnun Malibari, the Shattariah Tariqa had hundreds of huts and schools in Java and Sumatra (Rahmat, 2018a). At XIX, the Naqshbandiyah Tariqa dominated Muslim regions in Indonesia because the teachings were considered to be suitable by traditionalists (Hadarah \& Gani, 2019; Noupal, 2016). Meanwhile, TQN has the most followers of the congregation (M. Rais Ribha Rifqi Hakim, 2018).

Fourth, Sufism has strong roots from the Qur’ān and Hadith (Harun Nasution, 1990: 1-12), fifth, Tariqa, such as TQN Suryalaya, show their outstanding achievements by healing narcotics victims (Dadang Muliawan, 2017). Finally, the 
emptiness of life in the modern era drives people to glance at Sufism, and even Muhammadiyah intellectuals and figures have joined the Tariqa.

The Muhammadiyah organization rejects the Tariqa but runs a typical Sufism (Maisyaroh, 2019). Therefore, Sufism does not deviate from the path (Al-Kumayi, 2013), which seems to be a compromise of the pros and cons. The organization needed spiritual satisfaction to seek religious sensation (Khamami, 2016) and eventually accepted Sufism, such as increasing Salat, fasting, and reading the Qur`ān, but without Tariqa (Imam Masrur, 2019). Criticism of the Tariqa as an exclusive organization is indisputable, because every community must have an exclusive side (Fata, 2011). Meanwhile, senior professors at the Jakarta and Surabaya State Islamic Universities refuted minor views on Sufism and the Tariqa (Harun Nasution, 1990; Afandi, 2001: 9).

\subsection{Discussion of Sufistic Aspects}

The three aspects of the Sufism of thought, which are the obligatory khushi' Salat, the meaning and procedures of $d h i k r$, as well as the need for a Murshid Teacher, are discussed as follows.

\section{a. Discussion of the Obligation of Khushu`Salat}

Before learning, most students did not understand the meaning and importance of the khushu`Salat, and in one class, only one or two understood and considered it important. Consequently, it was explained that the essence of Salat in Sufism is khushu, which is to present God and remember Him during the prayers. This means that some special conditions need to be maintained until outside the Salat. Nasarudin Umar, a Sufism expert, emphasized that the Salat that presents the heart functions to connect the servant with God. The Sufi also quoted the Prophet's hadith, "Lā shalāta illā bi hudhûr al-qalb, whoch means "there is no Salat without the presence of the heart" (Nasarudin Umar, 2014). Hence, the Shattariah Tariqa emphasizes the order of the pillars of Islam. Salat can be solemn if the first pillar of Islam is correct, that is, it can "witness" the Divine Substance, and for this to occur, one must ask the expert or Wasithah teacher. After knowing the Divine Substance or Ma 'rifat bi Allāh, one must continue to practice dhikr by presenting and remembering the Divine Substance, which is the best way to practice when establishing Salat. Therefore, Tariqa encourages followers to increase their Salats and observe 34-73 rak'aat in their daily lives. After this, the obligatory Salat or tahajud must always be performed with the muqaddimah dhikr, which is dhikr after Sunset and Tahajud Salat, that serves to improve the memory of the heart to God (Rahmat, 2010). Meanwhile, NU emphasizes the khushu' Salat, avoids the sâhûn Salat (NUonline, 2019), and develop Tariqa (Kholid, 2018). Muhammadiyah also considers the importance of solemn Salat, even though it is emphasized to achieve perfection (Suara Muhammadiyah, 2019).

The Prophet's hadith, "The first charity examined by Allah is Salat, and if it is good, true, and khushu', then the other deeds are checked. But if it is bad, sâhûn, negligent, or does not remember Allah, then other deeds are thrown. Therefore, Salat is like the number one (1) in front and other charities are similar to zero (0) at the back, such that the number 100 is valuable, while 0,000,000,000,000 is worthless (Rahmat, 2010). During this illustration, some students showed their desire to offer a special Salat, and it was explained that the body and verbal practices perform the conditions of Salat, while having a heart of remembrance! A student asked, "Wow, this is very difficult! When Salats appear on things outside of God, such as remembering college assignments or lost items, etc., how should it be recited then?" The lecturer answered that "remembering God without the guidance of Murshid teacher is difficult, and this precise situation must make us aware that we are actually weak. Then, we should rise to ask God for forgiveness and guidance, and we may be forgiven and given instructions."

Sâhûn Salat is threatened with hell (Q.S. al-Ma un [107]: 4-5), and it is no wonder that the threatened ones are those that do not pray. But this is precisely for al-mushallîn or people that are accustomed to praying, but usually offer Salat that is sâhûn (Rahmat, 2010). This explanation disturbed many students and made them ask for practical instruction to avoid sâhûn Salat. Then, the lecturer explained, "do what is first. With Salat, we stay away from immoral acts, get rid of inferiority, and grow wonderful qualities. Hopefully, someday, Allah enables us to pray khushu` and avoid sâhûn Salat."

\section{b. Discussion of Meanings and Procedures of Dhikr}

Before learning, almost all students interpreted remembrance as wirid, performed after obligatory Salats, such as forgiveness, tasbih or purifying Allah, tahmid or praise, takbir or glorification, prayers, and reading the Qur'ān. Only one or two students per class understood dhikr as remembering Allah. However, the meaning of remembering Allah from their perspectives was to call Allâh and lâ ilâha illâ Allâh, an understanding that was certainly better.

Then, the lecturer explained the importance of dhikr, which according to Q.S. al-A raf [7]: 205 is a command to "wadzkur rabbaka fi nafsika tadharru an wa khîfatan," which means remember your Lord in your heart by humbling yourself and fearing Him." When worshiping Allah, e.g., when praying, God, who is to be worshipped, must be 
presented first. Q.S. al-Hijr [15]: 99 says "wa bud rabbaka hattâ ya tiyaka al-yaqîn," "meaning worship your Lord until you are sure that the God you worship is present," because the purpose of Salat is to remember Allah. Furthermore, Q.S. Thâhâ [20]: 14 declares "innanî anâ Allâh, lâ ilâha illâ anâ, fa ’budnî, wa aqîmi al-shalâta li al-dzikrî," which translates to "I am called Allah and there is no God besides Me. So, worship Me and establish Salat in remembrance of Me" (Rahmat, 2010). The remembrance of Allah in the heart is done during the Shattariah Tariqa together with breathing.

But what is the meaning of $\boldsymbol{d h i k r}$ ? Sufism and NU interpret it as a remembrance of Allah, and NU details three types, which are Asma or Name, Nature, and Substance (KH Said Aqil Siraj, 2013). Shattariah Tariqa interprets dhikr as remembrance of the Divine Substance (Rahmat, 2010), while Asma and Nature dhikr, which involve chanting the Name of Allah and His Attributes, are relatively easy. However, Substance $d h i k r$ is very difficult, because one must first Ma rifat bi Allâh or know the Divine Substance. Practicing Asma and Nature dhikr alone is good, and in TQN, dhikr is a verbal and heartfelt activity that involves reciting Allah's Name. There are two kinds of dhikr, which are jahr or loud, performed by reciting La iläha illä Allāh, and khafy, which is of the heart and done soundlessly by reciting the ism dzāt, such as Allah, Allah, etc. However, the TQN dhikr is only legal if it has been recited by the Murshid teacher (Marwa Salahudin \& Arkuni, 2016).

A student asked, "I once read a text, which stated that the essence of dhikr is to fulfill God's commands, just like a husband that remembers his wife and executes her message. When the husband brings something that was ordered by the wife, it means that he remembered her." The lecturer responded with an illustration again. "If the husband brings her order, but his heart carries another woman, does he really remember his wife?" Some female students answered, "Wow, then he is an unfaithful husband!" which was the precise answer the lecturer had been waiting for. Therefore, performing God's commands is one thing, and remembering Allah is another. The essence of worship is precisely remembering Allah and His Substance.

The lecturer further explained that Muhammadiyah meant dhikr by heart, oral, and of the limbs. Dhikr of the heart thinks of the postulates about the Substance of God, His attributes, commands, and the secrets of His creation. Oral dhikr involves praising Allah, glorifying, and reading the Qur'an. while dhikr of the body is a five-time Salat (Pimpinan Pusat Muhammadiyah, 2017). Therefore, it is possible to choose the meaning and practice of the dhikr that pleases a person.

Is the dhikr done individually or in congregations? Sufism and NU emphasize the good dhikr in congregation, although an individual performance is permissible. However, Muhammadiyah forbids $d h i k r$ in congregation and only allow it if the imam aims to teach it to pilgrims (Pimpinan Pusat Muhammadiyah, 2017). It is allowed to choose the way of dhikr that pleases one but the most important thing is that the Salat and other activities are not finished without dhikr first.

Dhikr with concentration when remembering God corresponds with the construction of Sufistic reasoning, which has four characteristics. These are making God the center, paying close attention to sincerity and special aspects, building religious affective and taste-based models with a spirit of moral enhancement and nobility of character. The last one is construction through inclusive and tolerant religious understanding (Futaqi, 2018). Dhikr practiced by remembering Allah while holding one's breath also corresponds with modern psychology. Conscious breathing is performed to find a feeling or dhawq that leads to comfort and inner peace. Dhawq can help people to know themselves, as well as acknowledge their weaknesses and shortcomings, to recognize the majesty and glory of God, approach, and grow in love for Him. First, breathing awareness is practiced meditatively and then improved by making it a means of physical and mental health, as well as a spiritual gain. Hence, the breath of consciousness is an essential exercise that culminates in the Creator (M. Iqbal Irham, 2016).

Dhikr is the method Sufi scholars employ to revive a dead heart by remembering Allah. It makes people aware of the existence of their Lord, because the essence is to witness the existence of Allah SWT. Meanwhile, jahr dhikr or khafy is done individually or in congregations (Faisal Muhammad Nur, 2017).

\section{c. Discussion of the Need of a Murshid Teacher}

Although almost none of the students knew Murshid teachers existed before learning, they were aware of the need to learn religion from scholars. However, they did not know the criteria of Ulama and for them, all preachers are Ulama, and often referreed to figures as such, especially those that were well-known preachers and from social media. Most students liked the cleric or preacher under their religious mindset, which was brought from their families and socialreligious environments. 
The lecturer explained that there was only one reference in that time, which was the Prophet, and the companions only used the Qur'ān and the Prophet's words when they were far from one another. With this reference, they often disagreed in that time, just like in today's world, but had one opinion after receiving explanations from the Prophet. Currently, the figure that can replace the Prophet's position as a religious reference or act as a substitute according to Sufism views is the Murshid teacher. Unlike the general Ulama, the Murshid teacher has a genealogy that can be linked to the previous Teacher and to the Prophet Muhammad. Although the agreed function is as an expert in $d h i k r$, the role of this teacher in each Tariqa is different. In the Shattariah Tariqa, the Wasithah Teacher is the Prophet's representative or successor, meaning that there is only one Wasithah Teacher in every age. However, in other Tariqas, such as in TQN, there may be more than one Murshid Teacher. The importance of this teacher was shown by al-Ghazāli, a Grand Shaykh or Hujjah al-Islam that studied with a Murshid. This Imam emphasized, "The guidance of a Shaykh or Murshid teacher is an absolute requirement for the success of religious development and without it, one will fall into error. Anyone that does not have a Shaykh is the teacher (A. K. Afandi, 2001); Akmansyah, 2015).

A student asked, "Why is the existence of the Murshid teacher unpopular? Is this proof that the scholars did not learn from the Murshid?" The lecturer explained, "That is wrong! The proof is that al-Ghazāli, Ibn Araby, as well as UIN professors like Harun Nasution and Azyumardi Azra studied with the Murshid. However, NU and Muhammadiyah emphasize the need to study with clerics that originate from the Prophet" (Romzi, 2012); (Isnanto, 2018). "Please, you are free to choose a view that is stronger and exhibits common sense."

\subsection{Discussion on Model Effectiveness}

PAI learning with a Sufi approach has proven effective in increasing students' understanding of Islam-Sufism, improving the quality of their diversity, and building religious tolerance. Before learning, students were generally unaware about Islam-Sufi and those that were mostly rejected it, while only a small proportion was accepting. However, after the six face-to-face lesson sessions, most students accepted it, and even a small proportion planned to practice it. After the study, most of the respondents thought that Sufism had a strong base in Islam.

The Sufistic approach can be said to be a learning model. Abas Asyafah explained that this model was generally viewed as a theoretical representation that is complex, broad, and deep into a concept that is simpler and easier to understand (Asyafah, 2014). Therefore, the developed approach has succeeded in simplifying the theory of Sufism and the Tariqa, which were complex, broad, and deep into a simpler concept.

The results of this research reinforce the findings of previous studies. These are, first, the Sufi Islamic approach has succeeded in increasing substantive-religiosity, noble morals, and religious tolerance at the Takeran Pesantren, which is the pioneer of modern Islamic boarding schools, founded by Kiai Hasan Ulama in 1886 AD (Rahmat, 2018a). Second, the approach has been proven to be successful in increasing the noble morals of students (Rahmat et al., 2016), particularly in enhancing their honesty (Rahmat \& Yahya, 2020). More broadly, the superiority of the madhhab typology method has increased students' understanding and acceptance of other religions and Islamic schools (Rahmat, 2018b), including NU-Muhammadiyah (Rahmat \& Fahrudin, 2018) and Shia Islam (Rahmat et al., 2020). Hence, the madhhab typology method has enhanced students' understanding and religious tolerance of different Islamic schools. Particularly, the Sufistic approach or typology of Sufi-Islamic Shari a schools, has succeeded in improving the quality of substantive and tolerant diversity.

\section{Conclusion}

Sufism has a fertile place in Indonesia, and a contributing factor is that NU practices Sufism and supports the Tariqa, while Muhammadiyah performs typical Sufism to improve the quality of religion. The two Sufi figures, Sheikh Abdul Qadir Jailani and al-Ghazāli are very popular. Also, Sufism has a strong basis from the Qur'ān and Hadith, and the Tariqa has a large following. The achievements of the Tariqa were brilliant in healing victims of drugs, and the void of life caused by modernization drives people to glance at Sufism. Meanwhile, many intellectuals even from the Muhammadiyah group joined the Tariqa, hence, it is appropriate to use this approach for PAI learning in universities. Finally, the results show the effectiveness of the Sufistic approach in increasing student acceptance of Sufism, the practice of higher quality Islam, and religious tolerance. The implication is that the Sufistic learning model is an alternative in learning Islamic education at universities.

\section{Acknowledgements}

The author is grateful to the Rector of Universitas Pendidikan Indonesia (Indonesia University of Education) and Deputi Bidang Penguatan Riset dan Pengembangan, Kementerian Riset dan Teknologi/Badan Riset dan Inovasi Nasional (the Deputy for Strengthening Research and Development, Ministry of Research and Technology/National Research and Innovation Agency) for providing useful financial support to complete this wonderful project. 


\section{References}

Afandi, A. K. (2001). "Ilmu Hakekat Kajian Tasawuf Syaththariyah.". In B. Afandi \& A. K. Afandi (Eds.), Satrio Paningit: Medal Ilmu Hakekat Sejati. Pustaka Pondok Sufi.

Akmansyah, M. (2015). Eksistensi Guru (Mursyid) Dalam Pendidikan Spiritual Perspektif Abû Hâmid Al-Ghazâlî (1058M-1111M). Al-Tadzkiyyah: Jurnal Pendidikan Islam, 6(November), 307-323.

Al-Kumayi, S. (2013). Gerakan Pembaruan Tasawuf di Indonesia. Jurnal Theologia (UIN Walisongo Semarang), 24(2), 247-278. https://doi.org/10.21580/Teo.2013.24.2.335.

Andarwati, L. (2016). Sufisme Perkotaan dan Pedesaan di Era Modernisasi dan Sekularisasi. Universum: Jurnal KeIslaman Dan Kebudayaan, 10(1), 41-48. https://doi.org/10.30762/universum.v10i1.222.

Anwar, C. R. B. (2002). Bertasawuf Tanpa Tarekat: Aura Tasawuf Positif. Hikmah.

Asyafah, A. (2014). The Method of Tadabur Qur'an: What Are the Student Views? International Education Studies, 7(6), 98-105. https://doi.org/10.5539/ies.v7n6p98.

Barnes, L. P. (2020). Religious education for free and equal citizens. British Journal of Religious Education. https://doi.org/10.1080/01416200.2020.1854687.

Clayton, M., \& Stevens, D. (2018). What Is the Point of Religious Education? Theory and Research in Education, 16(1), 65-81. https://doi.org/10.1177/1477878518762217.

Dabla, B. A. (1992). Dr. Ali Syari’ati dan Metodologi Pemahaman Islam. Al-Hikmah: Jurnal Pencerahan Pemikiran Islam, 4.

Dadang Muliawan. (2017). Komunikasi Terapeutik Korban Penyalahgunaan Narkoba melalui Tarekat. Ilmu Dakwah: Academic Journal for Homiletic Studies (UIN Sunan Gunung Djati Bandung), 11(1), 195-218. https://doi.org/10.15575/idajhs.v11i1.1530.

Faisal Muhammad Nur. (2017). Perspektif Zikir di Kalangan Sufi. Substantia: Jurnal Ilmu-Ilmu Ushuluddin (UIN ArRaniry Banda Aceh), 19(2), 189-198. http://dx.doi.org/10.22373/subtantia.v19i2.2884.

Fata, A. K. (2011). Tarekat. Jurnal Al-Ulum, 11(2), 373-384.

Fatmawati. (2013). Fungsi Tasawuf Terhadap Pembentukan Akhlak (Etika) Kerja: Studi pada Murid Tarekat Qadiriyah Naqsyabandiyah di Kota Pontianak Kalimantan Barat. Theologia (Jurnal Fakultas Ushuluddin Dan Humaniora UIN Walisongo Semarang), 24(2), 115-138. https://doi.org/10.21580/teo.2013.24.2.330

Firdaus, E., \& Rahmat, M. (2016). Learning Model of Religious Tolerance (A Study of The Increase of Life Cohesion for Students). The 1st UPI International Conference on Islamic Education. Islamic Education Faces Global Challenges, 151-155.

Futaqi, S. (2018). Nalar Sufistik Islam Nusantara Dalam Membangun Perdamaian. Dar El-Ilmi: Jurnal Studi Keagamaan, Pendidikan, Dan Humaniora (Universitas Islam Darul Ulum Lamongan), 5(2), 1-15.

Ghaffar, N. A. (2015). Tasawuf dan Penyebaran Islam di Indonesia. Rihlah: Jurnal Sejarah dan Kebudayaan, 3(1), 68-79. https://doi.org/10.1017/CBO9781107415324.004.

Hadarah, \& Gani, A. (2019). The Implementation of Tariqa Naqshbandiyah's Sufism Values in South Celebes. JSSER: Journal of Social Studies Education Research, 10(2), 243-269.

Harmathilda H. Soleh. (2017). Do’a Dan Zikir Dalam Meningkatkan Kecerdasan Emosi. Psikis: Jurnal Psikologi Islami (UIN Raden Fatah Palembang), 2(1), 29-39.

Harun Nasution. (1990). Thoriqot Qōdiriyah Naqsabandiyah: Sejarah. Asal Usul dan Perkembangannya. IAILM Suryalaya.

Hilal, I. (2002). Tasawuf antara Agama dan Filsafat: Sebuah Kritik Metodologis. Terjemahan. Pustaka Hidayah.

Howell, J. D. (2001). Sufism and the Indonesian Islamic Revival. The Journal of Asian Studies, 60(3), $701-729$. https://doi.org/10.2307/2700107.

Ibrahim, M. Z. (2002). Tasawuf Salafi: Mensucikan Tasawuf dari Noda-noda. Terjemahan. Hikmah.

Imam Masrur. (2019). Konsep Tasawuf Substantif Dalam Muhammadiyah. Spiritualita: Journal of Ethic and Spirituality (IAIN Kediri), 3(1), 73-103. https://doi.org/10.30762/spr.v3i1.1515.

Isnanto, M. (2018). Gagasan dan Pemikiran Muhammadiyah Tentang Kaderisasi Ulama (Studi Kasus tentang Ulama di Muhammadiyah). Aplikasia: Jurnal Aplikasi Ilmu-Ilmu Agama, 17(2), 95. 
https://doi.org/10.14421/aplikasia.v17i2.1380.

Iu Rusliana. (2016). Spiritualitas dalam Muhammadiyah. Syifa Al-Qulub: Jurnal Studi Psikoterapi Sufistik (UIN Sunan Gunung Djati Bandung), 1(1), 49-68. https://doi.org/10.15575/psy.v1i1.466.

Izzah Faizah Siti Khaerania, \& Yuyun Nurlaen. (2019). Makna Simbolik Zikir Pada Jemaah Tarekat Qadiriyah Naqsabandiyah (Studi Kasus Pada Jemaah Tarekat Naqsabandiyah di Pondok Pesantren Sirnarasa Ciamis). Jurnal Studi Agama Dan Masyarakat (LPPM IAIN Palangkaraya), 15(2), 87-97. https://doi.org/10.23971/jsam.v15i2.1331.

Ja'far, J. (2016). Tarekat dan Gerakan Sosial Keagamaan Shaykh Hasan Maksum. Teosofi: Jurnal Tasawuf Dan Pemikiran Islam, 5(2), 269. https://doi.org/10.15642/teosofi.2015.5.2.269-293.

KH Said Aqil Siraj. (2013). "Tiga Kategori Zikir kepada Allah.”Https://Www.Nu.or.Id/Post/Read/42619/TigaKategori-Zikir-Kepada-Allah, 19 Februari 2013. https://www.nu.or.id.

Khamami, A. R. (2016). Tasawuf Tanpa Tarekat: Pengalaman Turki dan Indonesia. Teosofi: Jurnal Tasawuf Dan Pemikiran Islam, 6(1), 1-28. https://doi.org/10.15642/teosofi.2016.6.1.1-28.

Kholid, A. R. I. (2018). Menuju Tuhan Melalui Tarekat (Kajian tentang Pemikiran Tasawuf). JURNAL YAQZHAN: Analisis Filsafat, Agama Dan Kemanusiaan, 4(1), 1-23. https://doi.org/10.24235/jy.v4i1.3187.

Kumala, O. D., Kusprayogi, Y., \& Nashori, F. (2017). Efektivitas Pelatihan Dzikir dalam Meningkatkan Ketenangan Jiwa pada Lansia Penderita Hipertensi. Psympathic: Jurnal Ilmiah Psikologi, 4(1), 55-66. https://doi.org/10.15575/psy.v4i1.1260.

M. Iqbal Irham. (2016). Nafas Kesadaran dan Menghidupkan Spiritualitas Melalui Integrasi Tasawuf dan Psikologi. TEOSOFI: Jurnal Tasawuf Dan Pemikiran Islam (UIN Sunan Ampel Surabaya), 6(1), 117-138. https://doi.org/10.15642/teosofi.2016.6.1.117-138.

M. Rais Ribha Rifqi Hakim. (2018). Strategi Dakwah pada Masyarakat Tarekat (Studi Kasus pada Kegiatan Tarekat Qodiriyah wa Naqsyabandiyah di Pondok Pesantren Futuhiyyah Mranggen, Demak). Lentera: Jurnal Ilmu Dakwah Dan Komunikasi, 2(1), 1-25. https://doi.org/10.21093/lentera.v1i3.1152.

Maisyaroh, M. (2019). Tasawuf sebagai Dimensi Batin Ajaran Islam. At-Tafkir, 12(2), 141-151. https://doi.org/10.32505/at.v12i2.1243.

Mannan, A. (2018). Esensi Tasawuf Akhlaki di Era Modernisasi. Aqidah-Ta: Jurnal Ilmu Aqidah, 4(1). https://doi.org/10.24252/aqidahta.v4i1.5172.

Marwa Salahudin, \& Arkuni, B. (2016). Amalan Tarekat Qadiriyah Wa Naqsabandiyah Sebagai Proses Pendidikan Jiwa Di Masjid Babul Muttaqin Desa Kradenan Jetis Ponorogo. Esoterik: Jurnal Akhlak Dan Tasawuf (IAIN Kudus), 2(1), 65-79. https://doi.org/10.21043/esoterik.v2i1.1619.

Nadzirotul Masruroh. (2018). Etika Islam dalam Perspektif Imam Al-Ghazālī. Empirisma: Jurnal Pemikiran Dan Kebudayaan Islam (LP2M IAIN Kediri), 1(1), 101-112. https://doi.org/10.30762/empirisma.v28i2.1646.

Nasarudin Umar. (2014). "Shalat, Perspektif Syariah, Tarekat, dan Hakikat (3)." Https://Www.Republika.Co.Id/Berita/Koran/Dialog-Jumat, 28 Mei 2014. ttps://www.republika.co.id.

Noupal, M. (2016). Tarekat Naqsabandiyah di Indonesia Abad 19 dari Ortodoksi ke Politisasi. INTIZAR: Jurnal Kajian Keislaman Dan Kemasyarakatan (LP2M UIN Raden Intan Palembang), $22(2), \quad 297$. https://doi.org/10.19109/intizar.v22i2.943.

NUonline. (2018, September). "Hukum Zikir dan Doa Berjamaah setelah Shalat Lima Waktu." Https://Islam.Nu.or.Id/Post/Read/96488/Hukum-Zikir-Dan-Doa-Berjamaah-Setelah-Shalat-Lima-Waktu, 30 September 2018. https://islam.nu.or.id.

NUonline. (2019). “Mengapa Harus Khusyu dalam Shalat?”Https://Islam.Nu.or.Id/Post/Read/51868/MengapaHarus-Khusyu-Dalam-Shalat, 29 Juni 2019. https://islam.nu.or.id.

Pimpinan Pusat Muhammadiyah. (2017). "Bagaimana Hukum Zikir Berjamaah Berdasarkan Fatwa Tarjih Muhammadiyah Tahun 2011?” Http://Www.Umm.Ac.Id/Id/Muhammadiyah/11595.Html, 8 Agustus 2017. http://www.umm.ac.id.

Qur`ān. (2013). Al-Qur 'ān in Digital Qur`ān ver 3.1. Kementerian Agama RI.

Rahmat, M. (2010). Proses Pendidikan Insan Kamil di Pondok Sufi Ilmu Syaththariah Pondok Pesantren Sumber Daya At-Taqwa Tanjunganom Nganjuk Jawa Timur. Alqalam: Jurnal Kajian Keislaman, 27(1), 1-40. 
https://doi.org/10.32678/alqalam.v27i1.578.

Rahmat, M. (2012). Corak Berpikir Keagamaan Mahasiswa (Eksklusif, Inklusif, dan Liberal). Taklim: Jurnal Pendidikan Agama Islam, 10(1), 13-37.

Rahmat, M. (2018a). Kiai Hasan Ulama Mursyid Tarekat Shaththariah As a Pioneer of Modern Pesantren. Jurnal Pendidikan Islam (UIN Sunan Kalijaga), 7(1), 1-22. https://doi.org/10.14421/jpi.2018.71.1-22.

Rahmat, M. (2018b). Model Perkuliahan Pendidikan Agama Islam Yang Damai, Moderat, dan Toleran. Nadwa: Jurnal Pendidikan Islam, 12(1), 39-64. https://doi.org/10.21580/nw.2018.12.1.2180.

Rahmat, M., \& Fahrudin. (2018), the Learning Model of Madhhab Typology Nu-Muhammadiyah in Islamic Religious Education. International Journal Pedagogy of Social Studies, 3(1), 57-78. https://doi.org/10.17509/ijposs.v3i1.10631.

Rahmat, M., Firdaus, E., \& Yahya, M. W. (2019). Creating Religious Tolerance through Quran-Based Learning Model for Religious Education. Jurnal Pendidikan Islam (UIN Sunan Gunung Djati), 5(2), 175-188. https://doi.org/10.15575/jpi.v5i2.6467.

Rahmat, M., Firdaus, E., \& Yahya, M. W. (2020). The Typology of The Sunni-Shia Madhhab: Can It Eliminate Student Hatred Towards Shia? In Review in Al-Jami 'ah: Journal of Islamic Studies.

Rahmat, M., Supriadi, U., \& Fahrudin. (2016). The Development of Sufistic `Core`Character-Based Quranic Stories Learning Model in Islamic Education for The Improvement of The Students` Behavior. Man in India, 96(12), 5099-5111.

Rahmat, M., \& Yahya, M. W. (2020). How to Improve the Honesty of Students in Indonesia? Sufism-Based Islamic Education Model As an Alternative. Accepted in International Journal of Education and Practice.

Rahmatul Husni. (2017). Sejarah Sufisme dan Pengaruhnya Terhadap Masyarakat Barat Modern. Jurnal Analisis Sejarah (Jurusan Sejarah Fakultas Ilmu Budaya Universitas Andalas), 6(1), 23-30.

Riyadi, A. K. (2018). Kajian atas Wacana Tasawuf dan Keutuhan Sosial Ernest Gellner. Teosofi: Jurnal Tasawuf Dan Pemikiran Islam, 8(2), 265-301. https://doi.org/10.15642/teosofi.2018.8.2.366-402.

Rizal, A. S., \& Rahmat, M. (2019). The Impact of Religious Obedience Against Religious Tolerance on Junior HighSchool Student. International Symposium on Social Sciences, Education, and Humanities, 306(ISSEH 2018), 185-188. https://doi.org/10.2991/isseh-18.2019.42.

Romzi, M. (2012). Ulama dalam Perspektif Nahdlatul Ulama. Religió: Jurnal Studi Agama-Agama (UIN Sunan Ampel Surabaya), 2(1), 40-58.

Sembodo Ardi Widodo. (2011). Konstruksi Keilmuan Muhammadiyah dan NU. Jurnal Al-Ulum, 11(2), 205-238.

Siregar, Q. A. (2012). Tasawuf dan Tarekat (Dimensi Esoteris Ajaran Islam). Jurnal Sosioteknologi, 11(27), 240-242.

Suara Muhammadiyah. (2019). "Shalat yang Tidak Khusyuk, Sah dan Diterima atau Tidak?" Https://Www.Suaramuhammadiyah.Id/2019/12/06/Shalat-Yang-Tidak-Khusyuk-Sah-Dan-Diterima-Atau-Tidak, 6 December, 2019. https://www.suaramuhammadiyah.id.

Sukmadinata, N. S. (2009). Metode Penelitian Pendidikan. PT Remaja Rosdakarya bekerjasama dengan Program Pascasarjana UPI.

Suryanegara, A. M. (1998). Menemukan Sejarah. Mizan.

Suteja. (2017). Pendidikan Karakter Berbasis Tasawuf. Jurnal Al Tarbawi Al Haditsah (IAIN Syekh Nurjati Cirebon), Vol. 1 No.(1), 23. https://doi.org/10.24235/tarbawi.v1i1.1225.

Taufani, T. (2018). Pengaruh Sufisme Di Indonesia. Potret Pemikiran, 20(1), 1-13. https://doi.org/10.30984/pp.v20i1.750.

\section{Copyrights}

Copyright for this article is retained by the author(s), with first publication rights granted to the journal.

This is an open-access article distributed under the terms and conditions of the Creative Commons Attribution license (http://creativecommons.org/licenses/by/4.0/). 